\title{
COMPARISON OF C AND N MINERALIZATION AND METAGENOME ANALYSIS OF RHIZOSPHERE SOILS BELONGING TO DIFFERENT Colchicum L. SPECIES
}

\author{
İpek EKICI*, Cengiz DARICI, Zahraddeen Kabir SANI, Sadık DINÇER \\ Biology Department, Science and Letter Faculty, Çukurova University, 01330 Sarıçam, Adana, TURKEY
}

Cite this article as:

Ekici İ., Darıcı C., Kabir S.Z. \& Dinçer S. 2022. Comparison of C and N mineralization and metagenome analysis of rhizosphere soils belonging to different Colchicum L. species. Trakya Univ J Nat Sci, 23(1): 1-13, DOI: 10.23902/trkjnat.971156

Received: 14 July 2021, Accepted: 01 October 2021, Online First: 15 November 2021, Published: 15 April 2022

\section{Edited by: \\ Dimitrios Mosialos \\ *Corresponding Author: Ipek Ekici \\ ipekekici@hotmail.com}

\section{ORCID iDs of the authors:}

IE. orcid.org/0000-0001-9838-9947

CD. orcid.org/0000-0003-0668-4127

ZKS. orcid.org/0000-0002-0993-1309

SD. orcid.org/0000-0002-0298-0917

Key words:

C. balansae

C. variegatum

C. triphyllum

Soil, carbon and nitrogen mineralization

Microbiota

Rhizosphere

\begin{abstract}
This study is aimed at determining the characteristics and microbiota of soil upon which some Turkish Colchicum (Colchicaceae) species naturally grows. For this aim the rhizosphere soil samples of Colchicum balansae Planch., Colchicum triphyllum Kunze and Colchicum variegatum L. were analysed in this research. The carbon mineralization rate of $C$. balansae soil at $\mathrm{p}<0.05$ is significantly different from that of the other two soils. In terms of nitrogen mineralization, significant difference exists between all the three soils $(\mathrm{p}<0.001)$. Colchicum variegatum rhizosphere was found to have the highest bacterial diversity. The results revealed that 254 bacterial species were common to the three rhizosphere soils, $35.60 \%$ of the bacterial species were unique to $C$. variegatum soil while $21.89 \%$ and $22.67 \%$ of the bacterial species were unique to $C$. balansae and $C$. triphyllum soil respectively. It was found that $C$. variegatum and $C$. balansae collected from areas close to each other had the highest number of common bacterial species, while $C$. triphyllum from the distant region shared 75 with $C$. variegatum and 19 with $C$. balansae. Metagenomics analysis reveals that in the rhizophere of $C$. variegatum, $C$. balansae and $C$. triphyllum, Actinobacteria is dominant at phylum level. Likewise, in C. variegatum soil, Nitrosocosmicus and halophilic Halobacter were found to be the dominant archaea. In the soils of $C$. triphyllum and C. balansae Saccharomycetales were detected, while Cryptococcus neoformans var. grubii H99 was exclusively detected in $C$. balansae soil. Significant difference $(\mathrm{p}<0.05)$ was observed in $C$. variegatum rhizosphere soil in terms of organic carbon $(\mathrm{C} \%)$ and carbon mineralization from the other two soil samples. Significant differences were observed in all three soils in terms of nitrogen content, and the C. triphyllum rhizosphere soil was significantly different from the others in terms of available phosphorus content $(p<0.05)$. This study showed that biological as well as the physico-chemical properties of the rhizosphere soil regulate soil microbial diversity and density and by extension influences their activity which evidently manifests itself in carbon and nitrogen mineralisation.
\end{abstract}

Özet: Bu çalışma, bazı Colchicum L. (Colchicaceae) türlerinin doğal olarak yetiştiği toprağın özelliklerini ve mikrobiyotasını belirlemeyi amaçlamaktadır. Bu amaç ile Colchicum balansae Planch., Colchicum triphyllum Kunze ve Colchicum variegatum L.'nin rizosfer toprak örnekleri analiz edilmiştir. Colchicum balansae toprağının karbon mineralizasyon oranı diğer iki toprağınkinden önemli ölçüde farklıdır $(\mathrm{p}<0,05)$. Azot mineralizasyonu açısından, her üç toprak arasında önemli bir fark vardır $(\mathrm{p}<0,001)$. Colchicum variegatum rizosferinin en yüksek bakteri çeşitliliğine sahip olduğu belirlendi. 254 bakteri türü üç rizosfer toprağında ortaktı, bakteri türlerinin $\% 35,60 ' 1$ C. variegatum toprağına özgüydü, bakteri türlerinin sirasılyla $\% 21,89$ 'u ve $\% 22,67$ 'si $C$. balansae ve $C$. triphyllum toprağına özgüydü. Birbirine yakın bölgelerden toplanan $C$. variegatum ve $C$. balansae'nin en fazla ortak bakteri türüne sahip olduğu (116), uzak bölgeden gelen $C$. triphyllum'un ise $C$. variegatum ile 75 ve $C$. balansae ile 19 'unu paylaştığı tespit edildi. Metagenomik analiz, $C$. variegatum, $C$. balansae ve $C$. triphyllum'un rizosferinde Actinobacteria'nın baskın bakteri filumu olduğunu ortaya koymaktadır. Bunun yanında $C$. variegatum toprağında Nitrosocosmicus ve halofilik Halobacter'in baskın arke olduğu bulunmuştur. Colchicum triphyllum ve C. balansae topraklarında Saccharomycetales tespit edilirken, Cryptococcus neoformans var. grubii H99 sadece C. balansae toprağında tespit edildi. Colchicum variegatum rizosferinde diğer iki toprak örneğinden organik karbon $(\% \mathrm{C})$ ve karbon mineralizasyonu bakımından önemli derecede farklılık $(\mathrm{p}<0,05)$ gözlenmiştir. Toprakta azot içeriği bakımından her üç toprakta anlamlı farklılık gözlenmiş olup yarayışlı fosfor içeriklerinde ise $C$. triphyllum diğerlerinden anlamlı derecede farklıdır $(\mathrm{p}<0,05)$. Bu çalışma, rizosfer toprağının biyolojik ve fiziko-kimyasal özelliklerinin, toprak mikrobiyal çeşitliliği ve yoğunluğunun karbon ve azot mineralizasyonuna olan etkilerini göstermektedir. 


\section{Introduction}

Organisms are colonised by microbes, which were found to have significant impacts on the development and health of their hosts (Berg et al. 2016, Mendes \& Raaijmakers 2015). The microbiome determining the health, development and productivity of a plant is generally regarded as the plant's second genome (Lakshmanan et al. 2014). Endosphere, rhizosphere and phyllosphere of plants provide microbial communities with specific functions. Substantial implication on the ecosystem arises due to fluctuations in plant - soil microbe interactions, because soil microbes influence plant growth and survivability through different mechanisms (Compant et al. 2019). To predict future ecosystem function, series of comprehensive study on microbial communities and plants as well as their reaction towards climate change became crucial (Classen et al. 2015). The properties of ecosystem are shaped and maintained via the interaction of soil microbes with one another and with the plant. Landscape patterns of animal and plant composition, abundance and diversity can be shaped by the aforesaid microbial interactions (Berg et al. 2010, van der Putten et al. 2013). Metagenomics analysis reveals that through conventional methods, only 5\% of bacteria has been successfully cultivated (Mendes \& Raaijmakers 2015). Berg et al. (2016) on studying the colonization of the rhizosphere of Solanum distichum Schumach. \& Thonn. (Nightshade) and Matricaria chamomilla L. (Chamomile) by microbes note that specific microbial communities are selected by different plants. As a result of exudate variation relative to plant developmental stages, specific microbial communities are selected at a time (Chaparro et al. 2013). As microbes proliferate in close proximity with a variety of host plants, fluctuations in environmental conditions influence their interactions amongst themselves and their plant hosts (Braga et al. 2016).

When the movement of soil organic matter in nature is examined, it is understood that each stage is interconnected and even dependent on each other. Organic wastes are first broken into small pieces by the soil fauna and mixed into the soil, so it is possible for other soil creatures to break down and decompose more easily. While all factors are at the optimum level, the change of even one factor affects this cycle, which is reflected in carbon mineralization (Ayilara et al. 2020).

Interactions between microbial communities in soil and plants are not unidirectional, the plant influences the type of microbial community that will become established around it by exuding nutrients and these microbial communities will establish a positive, neutral or negative relationship with the host plant (Thrall et al. 2007). In their interactions with plants, prokaryotic and eukaryotic microbes have evolved a myriad of cooperative and competitive mechanisms shaping microbial assemblages on plants (Hassani et al. 2018).

Recently, Turkey has been shown to be the richest country in terms of Colchicum L. diversity. Persson (2007) reported that the genus is represented with a total of 99 species in the world and approximately half of the 50 endemic species are distributed in Turkey (Uysal \&
Kaya 2019). From time immemorial, Colchicum species have been employed in treating numerous disorders due to their anti-inflammatory, therapeutic and anti-tumoral activities (Alali et al. 2007). According to their flowering time, Colchicum species have been categorized into two categories, viz. Hysanthous in which flowering occurs in autumn while leaves and fruits appear in spring and Synanthous in which both the flowers and the leaves emerge together in spring. Colchicum variegatum and $C$. balansae fall under the autumn flowering type while $C$. triphyllum falls under the spring flowering type (Toplan et al. 2016). Colchicum species have been found to be rich in phenolic acids, alkaloids, flavonoids, fatty acids and tannins (Evans 2002). The study is of great importance in terms of determining the microbial activities that reflect environmental changes in the most accurate and precise way and understanding the ecology of these plants under the threat of global warming.

\section{Materials and Methods}

\section{Sample collection}

The present study aimed to reveal and compare the carbon mineralization and microbial diversity of the rhizosphere soils of three Colchicum species, one of which is endemic, in different regions of Turkey.

The rhizosphere soils of $C$. variegatum, $C$. balansae and $C$. triphyllum were separately collected from MuğlaKale Road (37²'34.3” N, 28\%40'11.9” E) (mediterranean climate), Datça-Knidos Road (36 $46^{\circ} 31^{\prime \prime}$ $\mathrm{N}, 27^{\circ} 35^{\prime} 49^{\prime \prime}$ E) (mediterranean climate) and NiğdeÇamard 1 (37 $50^{\prime} 16^{\prime \prime} \mathrm{N}, 35^{\circ} 1^{\prime} 26^{\prime \prime}$ E) (terrestrial climate) Turkey, respectively. For each plant species, the rhizosphere soils were collected from each of the localities and soils of each locality were mixed homogeneously and analysed in triplicate.

\section{Physico-chemical analysis}

The soil samples were air dried. The air-dried soil samples were sieved and their $\mathrm{pH}$ values were measured (Jackson 1958). The organic carbon content of the samples were determined by the Anne method (Duchaufour 1970), and total nitrogen contents were evaluated by the Kjeldahl method (Bremmer 1965). Available phosphorus content (ppm) of the samples were determined following the description of Olsen (1954). Soil texture was identified according to Bouyoucos (1951), while $\mathrm{CaCO}_{3}$ content (Allison \& Moodie, 1965) and field capacity (Demiralay, 1993) were determined with Scheibler calcimeter and $1 / 3$ atm pressurized pump, respectively.

\section{Bacterial and fungal count determination}

Total bacterial count of each soil sample was determined using the Petroff-hausser counting chamber. 10 $\mathrm{g}$ of soil sample was added into $95 \mathrm{~mL}$ sodium pyrophosphate solution $(0.1 \% \mathrm{w} / \mathrm{v})$ contained in a beaker. The mixture was homogenized at room temperature on an orbital shaker at $100 \mathrm{rpm}$ for 30 minutes. The homogenized mixture was serially diluted $\left(10^{-1}\right.$ to $\left.10^{-6}\right)$ in sterile distilled water, $100 \mu \mathrm{l}$ aliquots from the dilution were plated on 
appropriate culture media [Tryptone Soya Agar (TSA) (Oxoid PO0163A, Basingstoke, Hampshire, England) for enumeration of total aerobic mesophilic and spore forming bacteria and modified Czapek Dox Agar (Oxoid CM0097) for fungal counts] and incubated at $30^{\circ} \mathrm{C}$. Aerobic mesophilic bacteria and spore forming bacteria were evaluated after 2 days of incubation, while fungal colony count was determined after 3 days incubation.

\section{Carbon and nitrogen mineralization determination}

In a $750 \mathrm{~mL}$ glass jar, $80 \mathrm{~g}$ of the air-dried soil was moistened up to $80 \%$ of its field capacity. A $50 \mathrm{~mL}$ beaker containing $10 \mathrm{~mL}$ of $1 \mathrm{M} \mathrm{NaOH}$ was placed at the middle of the jar containing the moistened soil. The jar was tightly sealed and incubated at $28^{\circ} \mathrm{C}$. Empty vessels served as blank control. After every 3 days of incubation, $2 \mathrm{~mL}$ of $\mathrm{BaCl}_{2}$ was added to the jar containing the $\mathrm{NaOH}$, a few drops of $0.1 \%$ phenolphthalein solution - an indicator - was added upon the emergent solution and $1 \mathrm{M}$ $\mathrm{HCl}$ was titrated upon the solution (Alef \& Nannipieri 1995). In place of the beaker that has been removed from the jar, another new beaker containing $10 \mathrm{~mL} 1 \mathrm{M} \mathrm{NaOH}$ was placed, the jar was tightly closed and taken back to the incubator. The carbon mineralized through microbial activity was expressed in $\mathrm{mg}$ per $100 \mathrm{~g}$ of dry soil [mg $\mathrm{C} / 100 \mathrm{~g}$ of dry soil]. The ratio of the carbon that undergoes mineralization to the total soil carbon is specified as the "Mineralization rate".

For nitrogen mineralization, soils moistened at $80 \%$ of the field capacity in jars closed with two layers of cloth in order to ensure correct and sufficient aeration were placed in an incubator at $28^{\circ} \mathrm{C}$. Soil samples were moistened every 2-3 days and incubated for 42 days. Measurements were made on the first and $42^{\text {nd }}$ days of incubation. To determine mineral nitrogen $\left(\mathrm{NH}_{4}+\mathrm{NO}_{3}\right)$ using the ParnasWagner procedure, $200 \mathrm{~mL}$ of $1 \mathrm{~N}$ calcium chloride was dispensed onto an appropriate amount of the soil sample, the mixture was agitated for 1 hour and distilled. Through dividing the amount of mineral nitrogen after 42 days of incubation by the amount of soil organic nitrogen, the nitrogen mineralization ratio of the soil was determined (Gökçeoğlu 1979, Lemee 1967).

\section{Metagenomic Studies}

Total DNA from the soil samples were isolated by using ZymoBIOMICSTM DNA Miniprep kit (Catalog number: D4300), (Zymo Research, USA) as described by the manufacturer. The forward and reverse primers: 27F (5'AGAGTTTGATCCTGGCTCAG-3'), 1492R (5'TACGGCTACCTTGTTACGACTT-3'), 21F (5'TTCCGGTTGATCCYGCCGGA-3'), 958R (5'YCCGGCGTTGAMTCCAATT-3'), EukF (5'AACCTGGTTGATCCTGCCAGT-3'), EukR (5'TGATCCTTCTGCAGGTTCACCTAC-3') were used for the amplification of the 16S rRNA gene of bacteria, fungi and archaea, respectively. DNA purity and concentration were analysed through $260 / 280 \mathrm{~nm}$ absorbance measure using NanoDrop spectrophotometer 2000 (Thermo Fischer scientific, USA).

\section{Sequence Analysis and Evaluation of the Results}

A sequencing protocol of 48 hours (R9.4) was performed with the aid of MinION ${ }^{\mathrm{TM}}$ [version 0.46.1.9 (R9.4)] control software. The read data was obtained based on the 1.2.2 rev 1.5 workflow and software Metrichor $^{\mathrm{TM}}$ agent (version 0.16.37960). After the sequencing was completed, the results obtained in fast5 format were converted to fastq format using the guppy v3.1.5 software (base-calling and de-multiplexing). Barcode and adapter sequences were cleared using Porechop v. 0.2.3 software, and universal primers and labels were deleted by deleting 45 bases from both ends of the sequences. After the sequences were cleaned, the reads at 1300-1500 bp length were filtered and the remaining readings were excluded from analysis.

The cleaned readings were analysed with a customized workflow using the mothur v. 1.39.5 platform. Sequences were purified from chimeric structures, by measuring the distances between them with the similarity matrix to be aligned relative to each other, the readings showing more than $99 \%$ similarity were clustered and operational taxonomic units (OTUs) were formed. The generated OTUs were compared according to the RDP 16S rRNA database and their taxonomic annotations were performed and the OTUs that were determined as the same genus were associated and statistical results were obtained. Primer sequences used in sequencing were extracted from the raw data obtained from the Miniseq device. Primerfree reads were matched to each other. The matched reads were searched in the bacteria taxon database. The biome format was obtained and converted to grass format. QIIME II software (Bolyen 2019) was used for Alphabeta diversity analysis from the grass table. Basic coordinate analyses were also executed relative to the organisms with whose OTUs are matched and their quantitative values were obtained.

\section{$\underline{\text { Statistical analysis }}$}

All data obtained from the experiment were statistically analysed using SPSS windows (version 15.0, 2006). To determine significance differences existing between the different soil samples, One-Way ANOVA and Tukey HSD multiple comparisons tests were conducted. Differences between treatments were considered significant at $\mathrm{p} \leq 0.05$.

\section{Results}

The physico-chemical characteristics of the analysed soil samples are presented in Table 1.

Daily carbon mineralization curves clearly show the changes that occurred during organic matter decomposition in the soils (Fig. 1). According to the curves of cumulative carbon mineralization, the carbon mineralization in the rhizosphere soil of $C$. variegatum was higher than that of others (Fig. 2). The rhizosphere of $C$. balansae was found to have the highest carbon mineralization rate $(3.66 \%)$ and a carbon content of $1.37 \%$ which is lower than that of its counterparts (Fig. 3). This signifies that the organic matter present in this rhizosphere soil is easily mineralised. 
Table 1. Physico-chemical characteristics of the soil samples analysed.

\begin{tabular}{|c|c|c|c|}
\hline & C. variegatum & C. balansae & C. triphyllum \\
\hline Sandy (\%) & $63.52 \pm 0.01^{*} \mathrm{c}^{* *}$ & $68.43 \pm 0.01 b$ & $79.05 \pm 0.01 \mathrm{a}$ \\
\hline Silt (\%) & $32.32 \pm 0.01 \mathrm{a}$ & $20.24 \pm 0.01 \mathrm{c}$ & $13.61 \pm 0.01 \mathrm{~b}$ \\
\hline Clay (\%) & $4.16 \pm 0.01 \mathrm{c}$ & $11.33 \pm 0.01 \mathrm{a}$ & $7.34 \pm 0.01 b$ \\
\hline Texture & Sandy loam & Sandy loam & Loamy sand \\
\hline $\begin{array}{l}\text { Field } \\
\text { capacity }(\%)\end{array}$ & $23.57 \pm 0.01 \mathrm{a}$ & $18.57 \pm 0.01 b$ & $18.21 \pm 0.01 \mathrm{c}$ \\
\hline $\mathrm{CaCO}_{3}$ & $0.53 \pm 0.37 \mathrm{~b}$ & $0.19 \pm 0.10 b$ & $9.31 \pm 0.49 \mathrm{a}$ \\
\hline pH & $7.64 \pm 0.14 \mathrm{a}$ & $7.63 \pm 0.04 \mathrm{a}$ & $7.86 \pm 0.12 \mathrm{a}$ \\
\hline $\mathrm{C}(\%)$ & $4.00 \pm 0.06 \mathrm{a}$ & $1.37 \pm 0.17 b$ & $1.87 \pm 0.12 b$ \\
\hline $\mathbf{N}(\%)$ & $0.24 \pm 0.06 \mathrm{a}$ & $0.04 \pm 0.01 \mathrm{c}$ & $0.17 \pm 0.04 \mathrm{~b}$ \\
\hline $\mathbf{C} / \mathbf{N}$ & $16.68 \pm 0.34 \mathrm{c}$ & $34.67 \pm 2.91 \mathrm{~b}$ & $10.99 \pm 0.70 \mathrm{a}$ \\
\hline $\mathrm{P}_{2} \mathrm{O}_{5}(\mathrm{~kg} / \mathrm{da})$ & $7.17 \pm 0.14 b$ & $6.04 \pm 0.48 b$ & $14.76 \pm 0.91 \mathrm{a}$ \\
\hline
\end{tabular}

"Values represent the means \pm standard error of triplicate analysis. ${ }^{* *}$ Different letter in each row denote significant differences $(\mathrm{p} \leq 0.05)$ by Tukey's post-hoc test in ANOVA.

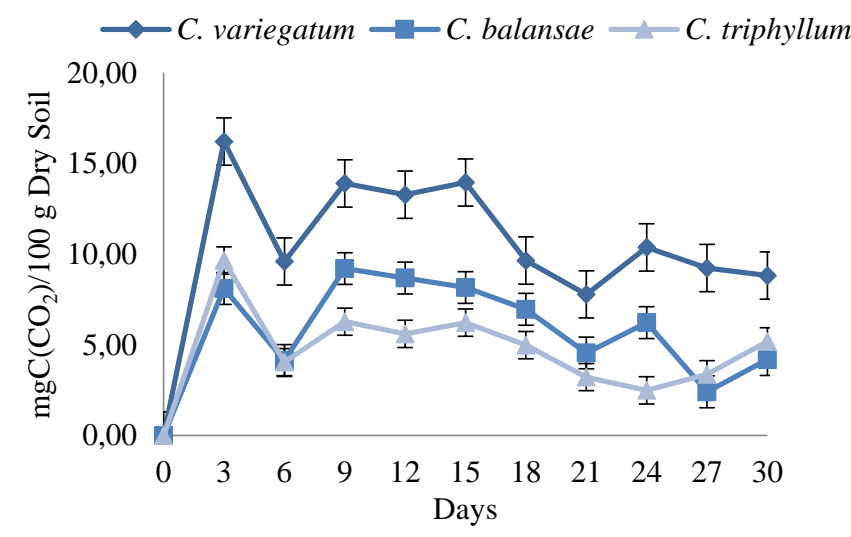

Fig. 1. Daily carbon mineralization, [mg C $\left(\mathrm{CO}_{2}\right) / 100 \mathrm{~g}$ Dry Soil]

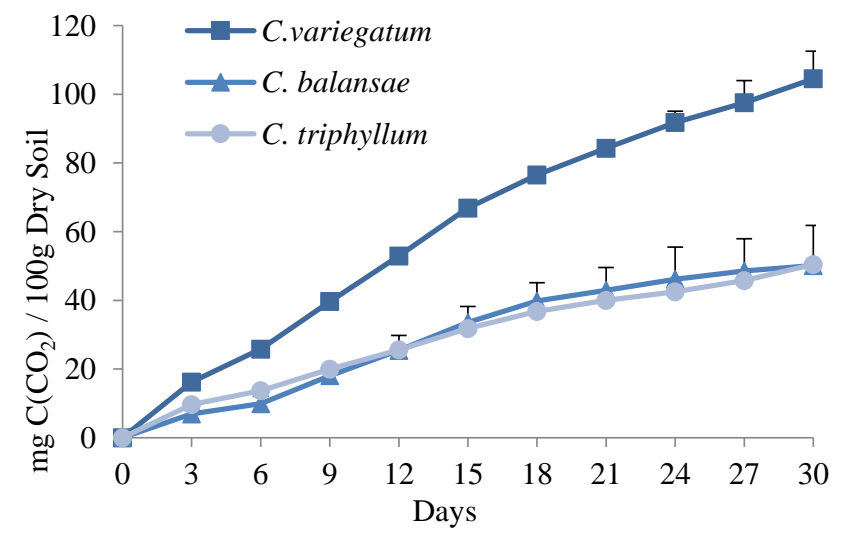

Fig. 2. Cumulative carbon mineralization $\left[\mathrm{mg} \mathrm{C}\left(\mathrm{CO}_{2}\right) / 100 \mathrm{~g}\right.$ Dry Soil]

After 42 days of incubation, $C$. variegatum rhizosphere soil was found to have the lowest nitrogen mineralization rate followed by that of $C$. triphyllum while $C$. balansae rhizosphere soil was found to exhibit the highest nitrogen mineralization rate (Table 2).
The $C$. variegatum rhizosphere soil sample was found to exhibit total aerobic mesophilic bacterial count of $1.3 \times 10^{4} \mathrm{cfu} / \mathrm{mL}$, spore forming bacterial count of $2 \times 10^{4}$ $\mathrm{cfu} / \mathrm{mL}$ and fungal count of $4.3 \times 10^{4} \mathrm{cfu} / \mathrm{mL}$.

Colchicum balansae rhizosphere soil sample was found to exhibit total aerobic mesophilic bacterial count of $0.7 \times 10^{4} \mathrm{cfu} / \mathrm{mL}$, spore forming bacterial count of greater than $0.5 \times 10^{4} \mathrm{cfu} / \mathrm{mL}$ and fungal count of $1.3 \times 10^{4}$ $\mathrm{cfu} / \mathrm{mL}$. While the rhizosphere soil sample of $C$. triphyllum was found to have aerobic mesophilic bacterial count of $1.4 \times 10^{4} \mathrm{cfu} / \mathrm{mL}$, spore forming bacterial count of greater than $1 \times 10^{4} \mathrm{cfu} / \mathrm{mL}$ and fungal count of $6.7 \times 10^{4}$ $\mathrm{cfu} / \mathrm{mL}$.

The read counts of C. variegatum, $C$. balansae and, $C$. triphyllum rhizosphere soil samples were determined to be $32,400,27,800$ and 32,200 respectively. The total OTUs of $C$. variegatum, $C$. balansae and $C$. triphyllum were determined to be $21,483,18,747$ and 22,961 respectively.

The rhizosphere soil of $C$. balansae was found to have the highest proportion of eukaryotic microorganisms with Cryptococcus neoformans var. grubii $\mathrm{H} 99$ been dominant with an abundance of $45 \%$, the $4-7 \%$ human DNA found in this rhizosphere can be attributed to contamination of the sample with human remains due to handling or anthropogenic activities in the area (Fig. 4).

Since eukaryotic microorganisms have the ability to decompose polysaccharides that the Bacteria domain cannot biologically break down into smaller constituents with their exoenzymes, the diversity and proportional excess of eukaryotic microorganisms seen in C. balansae soil support the high carbon and nitrogen mineralization rates in this soil. In the rhizosphere soil of $C$. triphyllum Saccharomycetales - which play a substantial role in carbon cycle - were found to be the dominant eukaryotes with an abundance of $41 \%$, so also Beta vulgaris subsp. vulgaris L. was found to be $31 \%$ abundant in the rhizosphere soil sample of $C$. triphyllum (Fig. 5), this emanate from $B$. vulgaris subsp. vulgaris plants growing at the location from which the samples were collected.

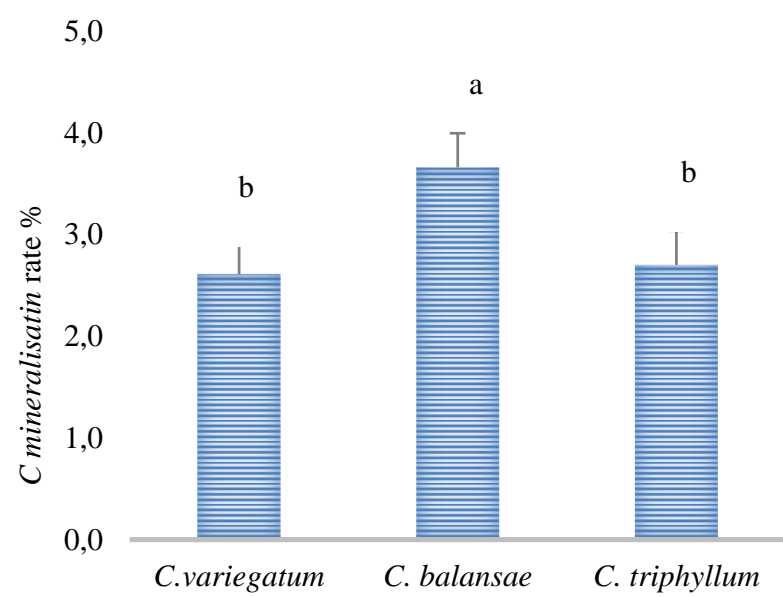

Fig. 3. Carbon mineralization rate (\%) 


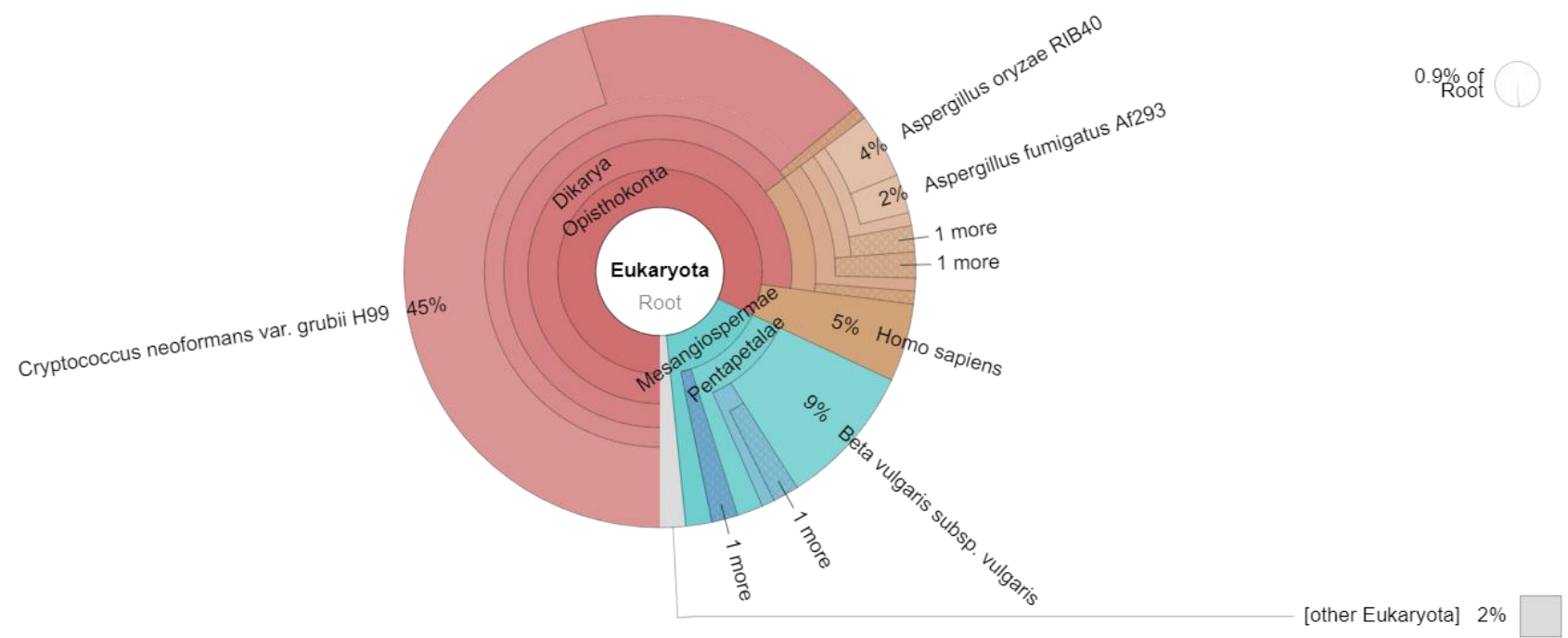

Fig. 4. Composition and abundance of domain Eukaryota in rhizosphere soil of Colchicum balansae.

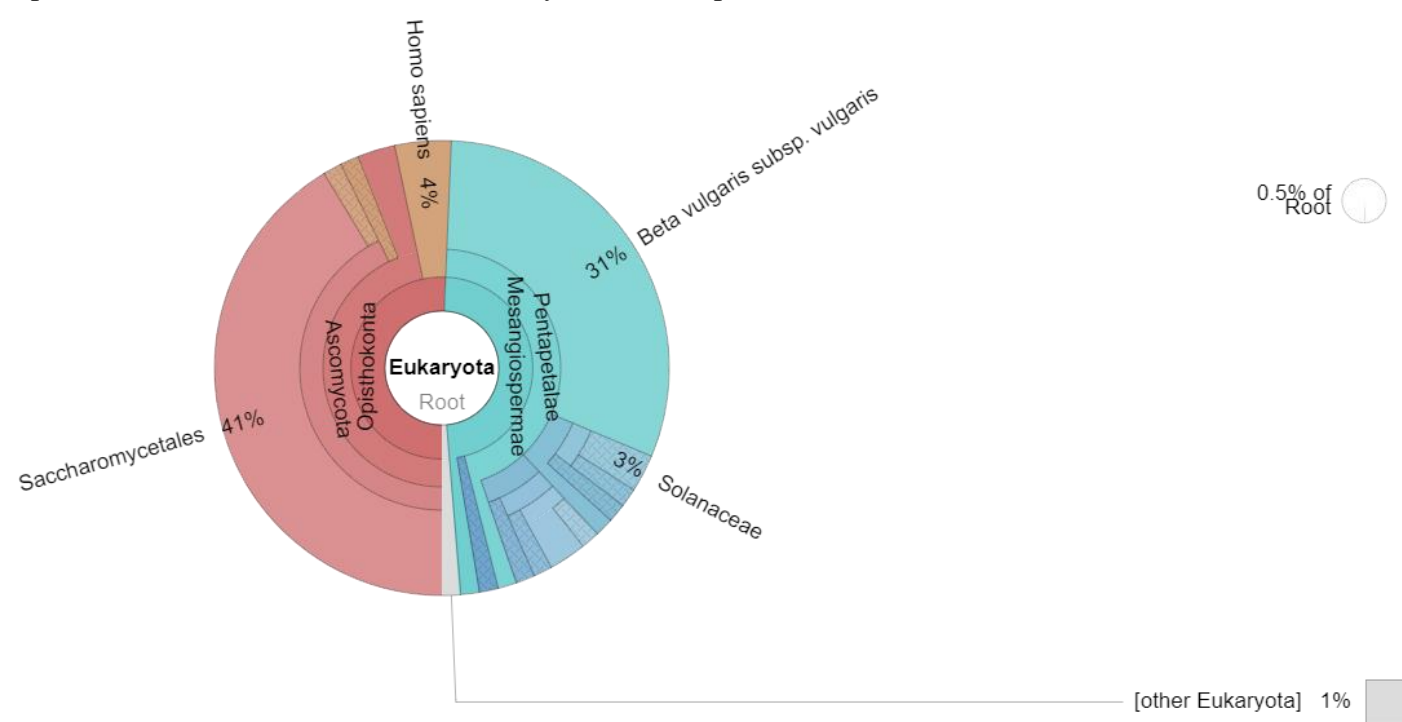

Fig. 5. Composition and abundance of domain Eukaryota in rhizosphere soil of C. triphyllum.

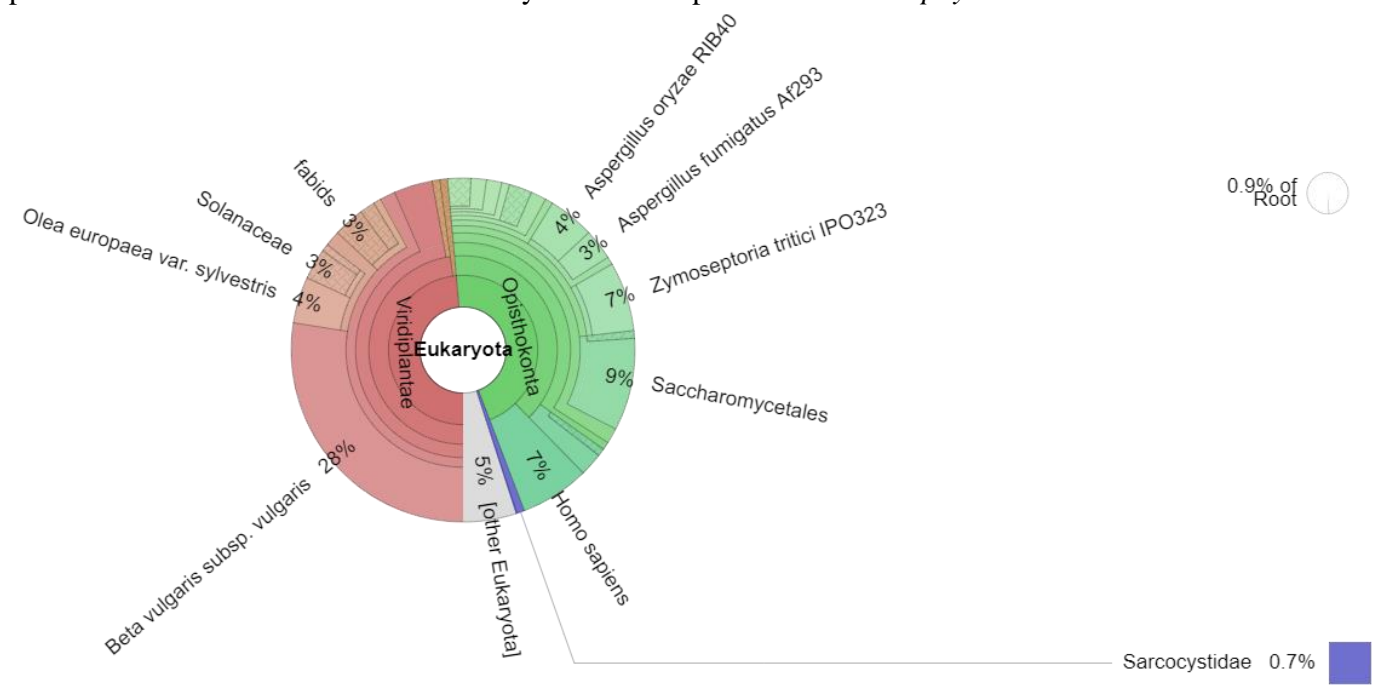

Fig. 6. Composition and abundance of domain Eukaryota in rhizosphere soil of C. variegatum 
While the rhizosphere soil of $C$. variegatum was found to be the least in eukaryotic microbes abundance with Saccharomycetales been prominent (Fig. 6).

Figs 7-9 presents the percentage abundance of Archaea present in the analysed soil samples. Haloprofundus sp. MHR1 was found to be common to both $C$. variegatum and $C$. balansae rhizosphere soil samples occurring in $20 \%$ and $7 \%$ abundance respectively. Likewise, Thermococcus was found to be common to the rhizosphere soil samples of $C$. balansae and $C$. triphyllum at percentage abundance of $7 \%$ and $8 \%$ respectively. So also, the archea Candidatus, Nitrosocosmicus franklandus were found to be common to the rhizosphere soil samples of C. variegatum (20\% abundance) and $C$. triphyllum (33\% abundance). Candidatus nitrosonia, was found to be unique $C$. variegatum rhizosphere soil sample.

The abundance of bacterial phyla of the analysed rhizosphere soil was presented in Figs 10-12. It can be deduced that environmental factors as well as plant type influences the quantity, quality and diversity of soil microbial content.

Metagenomic analysis reveals the diversity in bacterial phyla amongst the rhizosphere of the 3 different plants with dominance of Actinobacteria, Proteobacteria, Chloroflexi and Acidobacteria (Fig. 13).

Actinobacteria were found to be the dominant class in the rhizosphere of $C$. balansae and $C$. triphyllum while in the rhizosphere of $C$. variegatum, the dominant class was found to be Thermoleophilia (Fig. 14).

Metagenomic analysis reveals the diversity in bacterial phyla amongst the rhizosphere of the 3 different plants with dominance of Actinobacteria, Proteobacteria, Chloroflexi and Acidobacteria (Fig. 13).

Actinobacteria were found to be the dominant class in the rhizosphere of $C$. balansae and $C$. triphyllum while in the rhizosphere of $C$. variegatum, the dominant class was found to be Thermoleophilia (Fig. 14).

Table 2. Nitrogen mineralization $(\mathrm{mg} / \mathrm{kg})$ rates $(\%)$.

\begin{tabular}{cccccc}
\hline \hline & $\begin{array}{c}\text { Day 1 (mg/kg) } \\
\text { NH4-N }\end{array}$ & NO3-N3 & $\begin{array}{c}\text { Day 42 (mg/kg) } \\
\text { NH4-N }\end{array}$ & NO3-N & N min rate $(\%)$ \\
\hline \hline C. variegatum & $26.99 \pm 0.50^{*} \mathrm{~b}^{* *}$ & $5.12 \pm 0.21 \mathrm{~b}$ & $38.80 \pm 2.11 \mathrm{a}$ & $30.06 \pm 1.64 \mathrm{~b}$ & $2.87 \pm 0.14 \mathrm{c}$ \\
C. balansae & $28.82 \pm 0.40 \mathrm{a}$ & $4.33 \pm 0.53 \mathrm{~b}$ & $39.25 \pm 0.44 \mathrm{a}$ & $13.75 \pm 0.31 \mathrm{c}$ & $13.25 \pm 0.17 \mathrm{a}$ \\
C. triphyllum & $24.72 \pm 0.11 \mathrm{c}$ & $74.21 \pm 7.10 \mathrm{a}$ & $37.37 \pm 1.57 \mathrm{a}$ & $84.81 \pm 3.09 \mathrm{a}$ & $7.19 \pm 0.10 \mathrm{~b}$ \\
\hline \hline
\end{tabular}

*Values represent the means \pm standard error of triplicate analysis. ${ }^{* *}$ Different letter in each column denotes significant differences as $\mathrm{p} \leq 0.05$ by Tukey's post-hoc test in ANOVA.
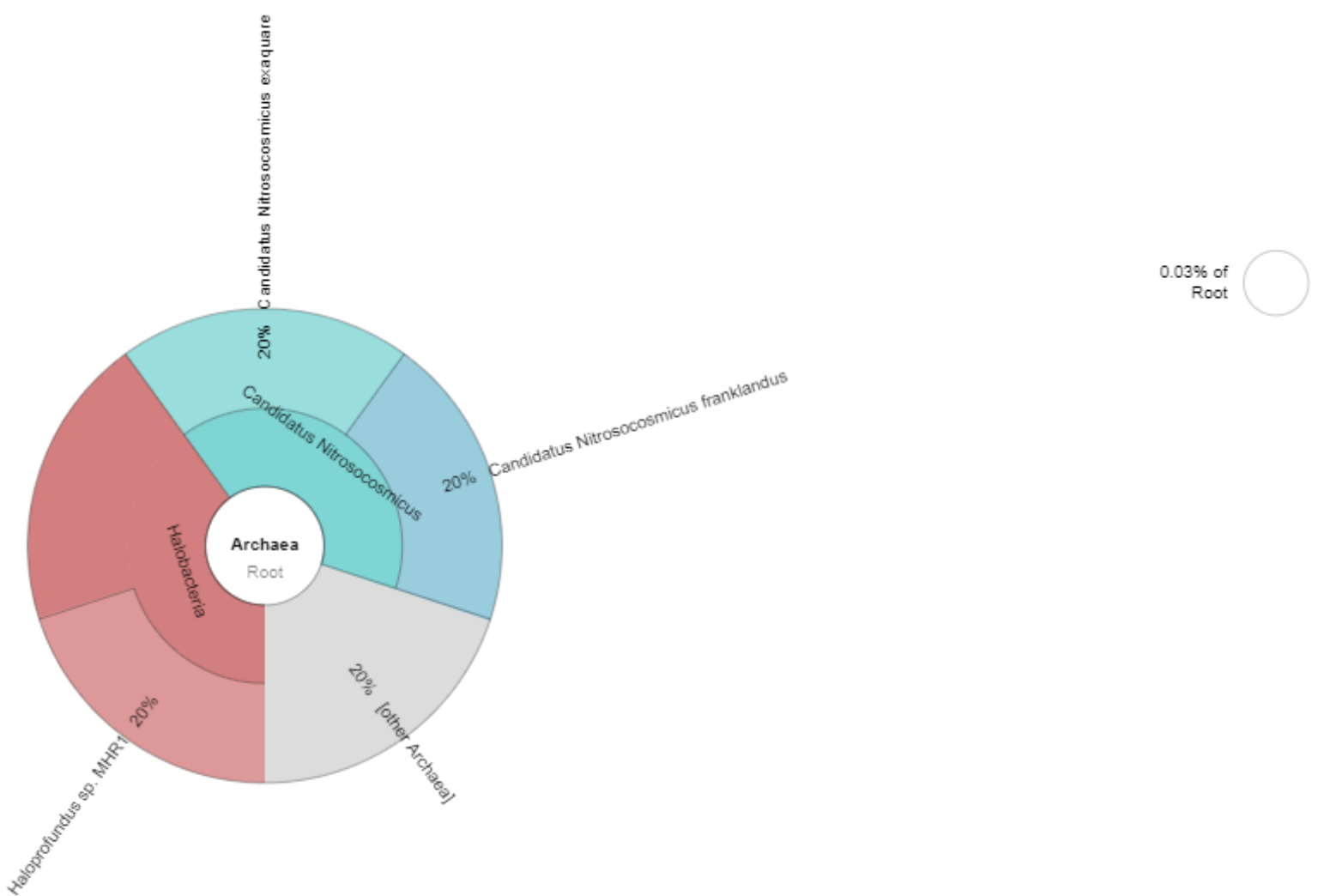

Fig. 7. Composition and abundance of domain Archaea in C. variegatum rhizosphere. 


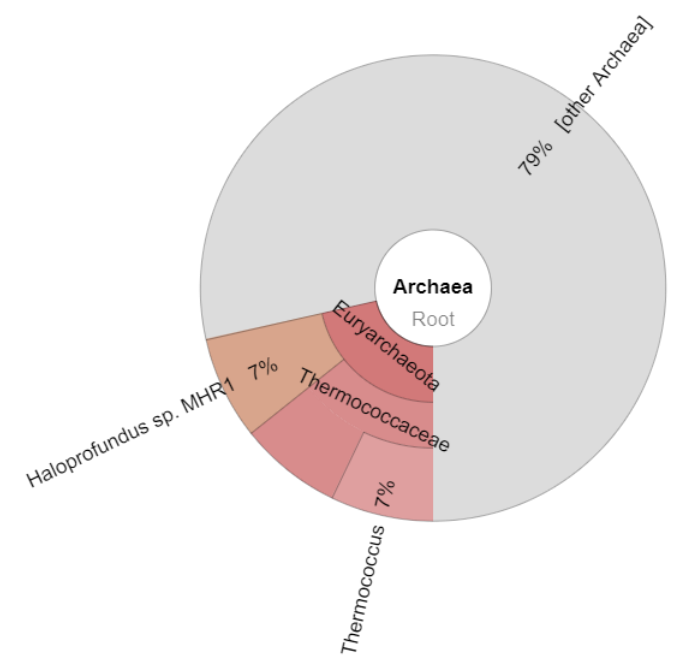

Fig. 8. Composition and abundance of domain Archaea in C. balansae rhizosphere.

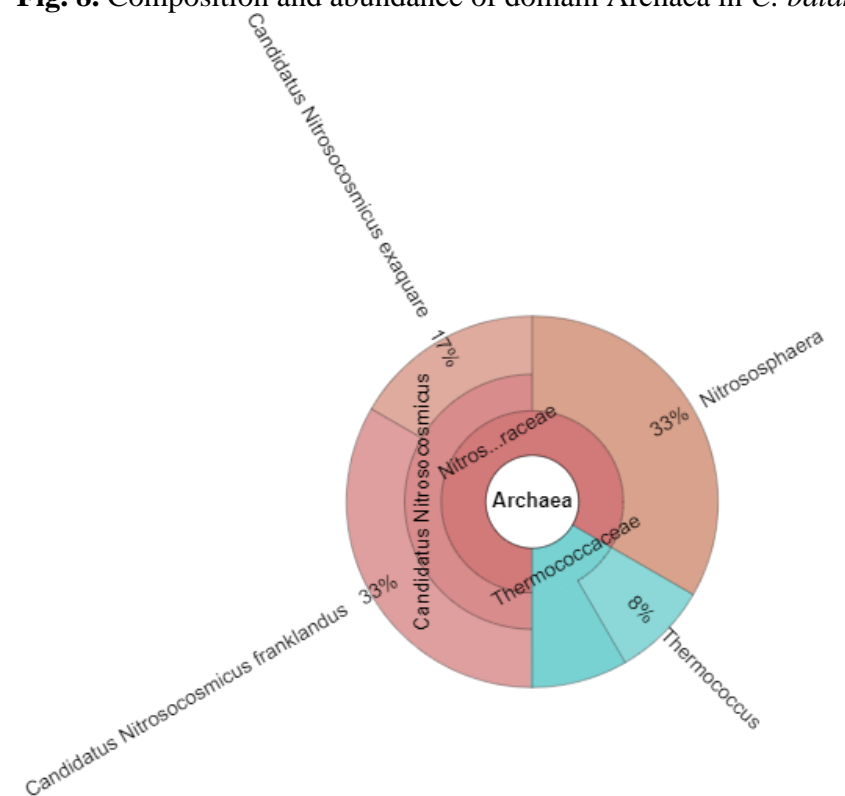

Fig. 9. Composition and abundance of domain Archaea in C. triphyllum rhizosphere.

Fig. 15 presents the percentage composition of bacteria genera in the three rhizosphere soils analysed. In C. balansae and C. triphyylum rhizosphere, Microvirgabelonging to the methylobacteriaceae- abundance was found to be higher in comparison to that found in the rhizosphere of $C$. variegatum. The percentage abundance of Azospirillum and Nitrospira genera were found to be higher in the rhizosphere of $C$. balansae.

Fig. 16 shows the bacterial species recorded in the three rhizospheres that were analysed metagenomically. The most bacterial species were found in the $C$. variegatum rhizosphere. Among all three rhizosphere soils, it was determined that $35.60 \%$ of the bacterial species in $C$. variegatum rhizosphere soil, and $21.89 \%$ and $22.67 \%$ of $C$. balansae and $C$. triphyllum, respectively, and they were unique bacterial species. It has been also observed that 254 bacterial species were common to the three rhizosphere soils. It was determined that 116 bacterial species in $C$. variegatum and $C$. balansae soils collected from regions close to each other were common only in the rhizosphere soil among the analysed soils. It was also found that 75 bacterial species were common to $C$. variegatum and $C$. triphyllum while 19 bacteria were found to be common to the $C$. triphyllum and C. balansae rhizosphere soils.

The dominant species in $C$. variegatum rhizosphere where Conexibacter woesei DSM 14684 (2\%), Plantactinospira spp. BC1 (1\%), Burkholderia pseudomallei $(0,8 \%)$, Frankia alni $(0,8 \%)$. In the rhizosphere of $C$. balansae; C. woesei DSM 14684 (3\%), Plantactinospira sp. BC1 (3\%), Solibacter usitatus (1\%), M. dispar (1\%), Baekduia soli (1\%) were found to be the dominant species while in the rhizosphere of $C$. triphyllum the dominant species were Plantactinospira spp. BC1 (3\%), Mycoplasma dispar (3\%), Kribbella flavida (2\%), C. woesei DSM 14684 (2\%) and Rubrobacter indicoceani (2\%).

Alpha-Beta diversity analysis of the three analysed soil samples shows that $C$. balansae with Shannon index of 8.325 has greater diversity than $C$. variegatum and $C$. triphyllum whose index is 8.305 and 8.210 respectively (Fig. 17). 


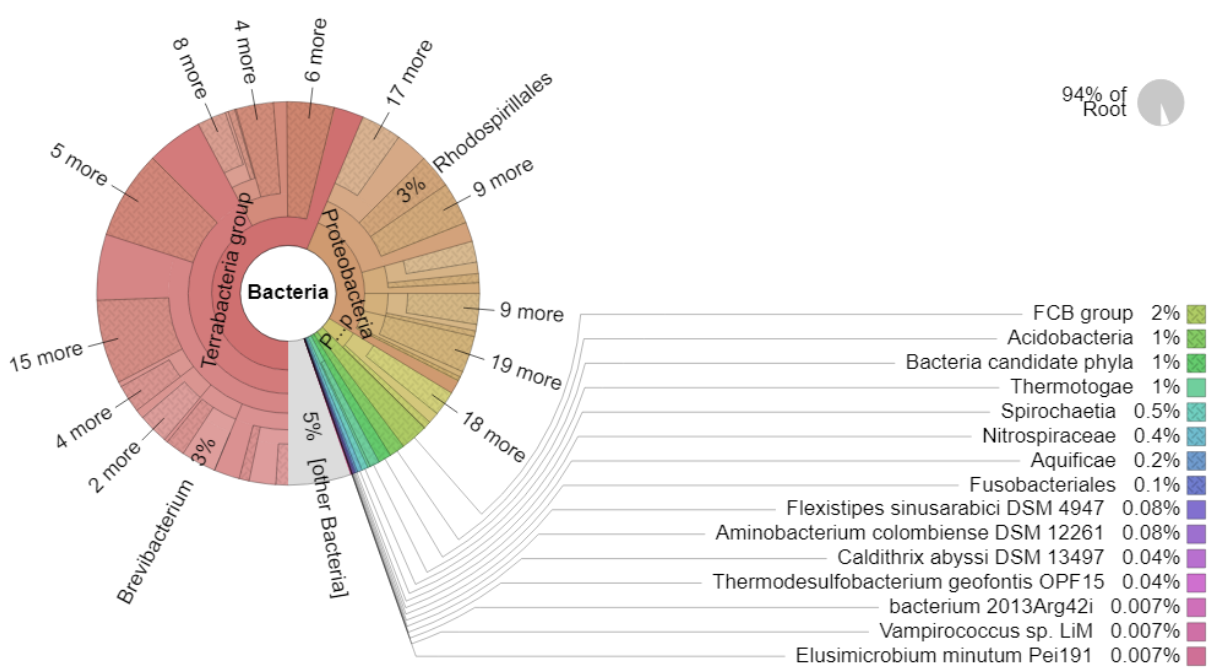

Fig. 10. Composition and abundance of domain Bacteria in C. variegatum rhizosphere

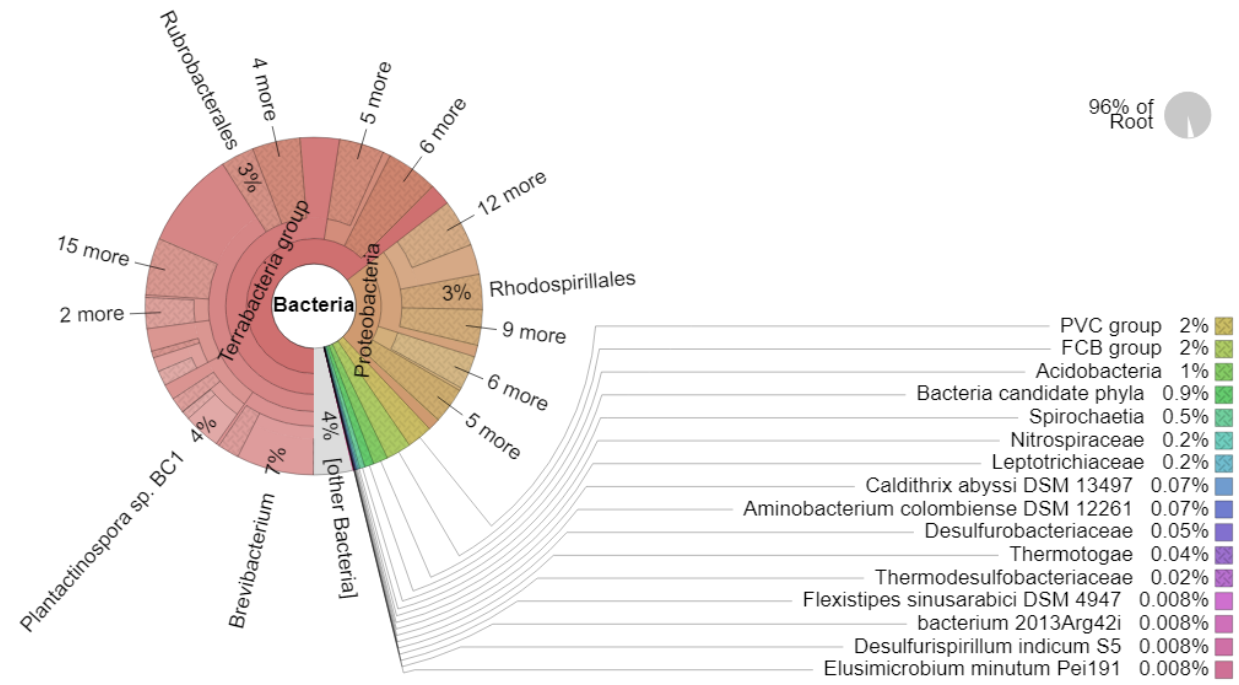

Fig. 11. Composition and abundance of domain Bacteria in C. balansae rhizosphere

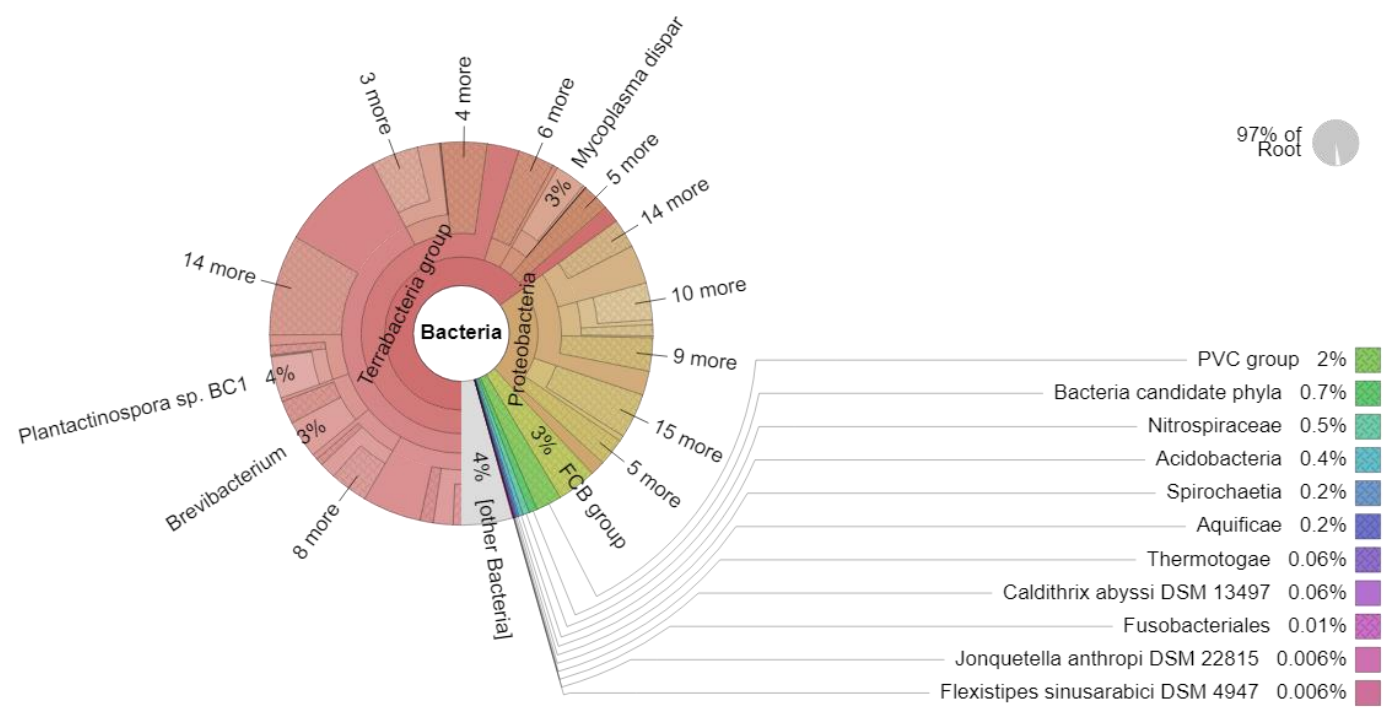

Fig. 12. Composition and abundance of domain Bacteria in C. triphyllum rhizosphere 


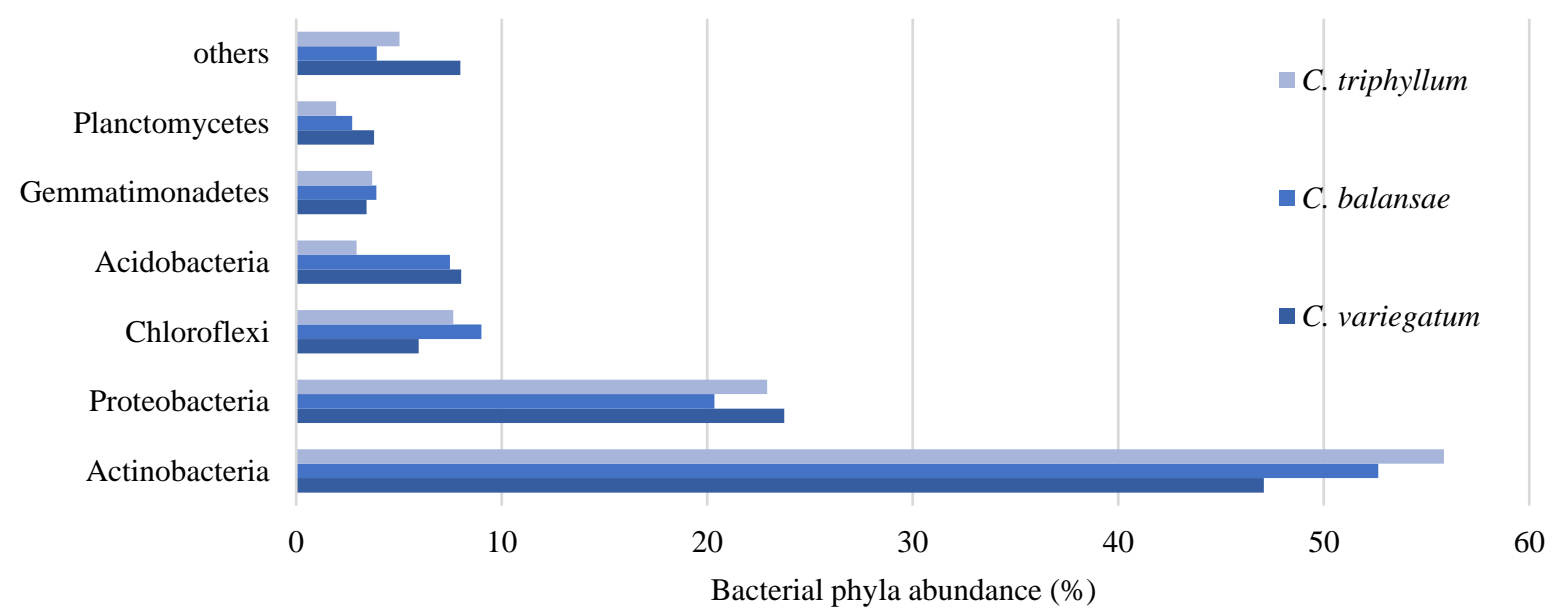

Fig. 13. Taxonomic distribution of identified bacteria in rhizosphere soil samples at phyla-level.

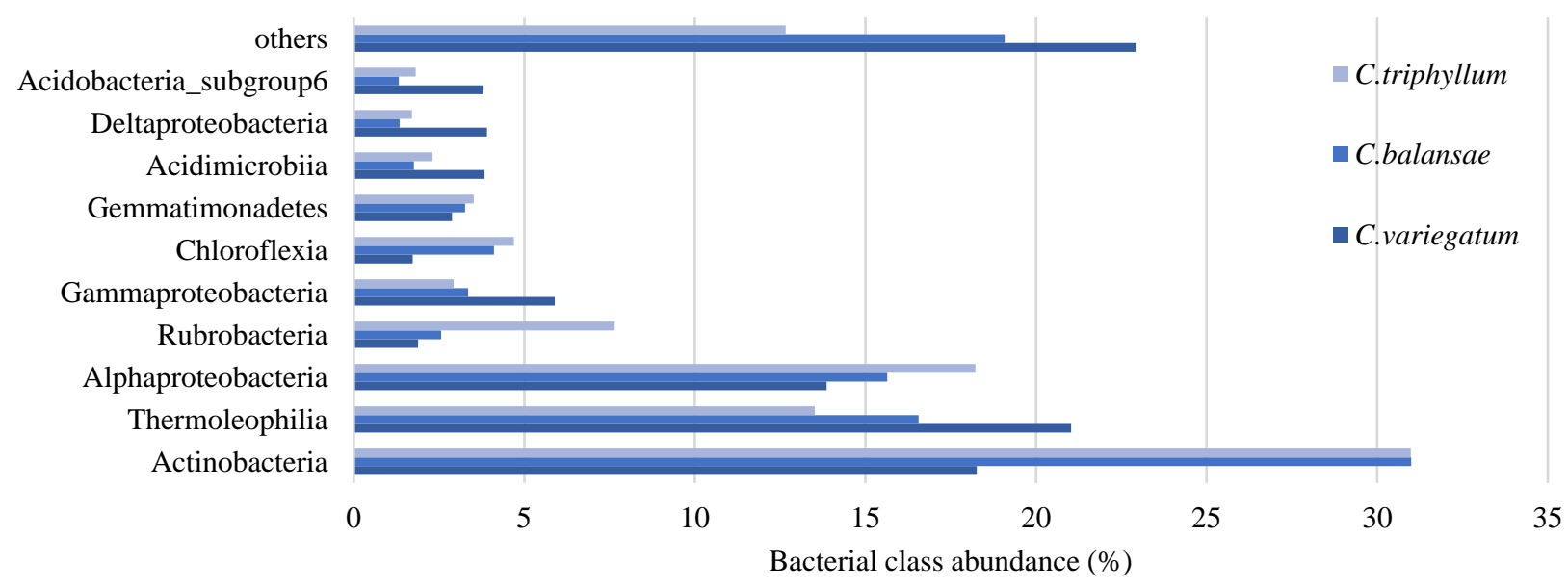

Fig. 14. Taxonomic distribution of identified bacteria in rhizosphere soil samples at class-level.

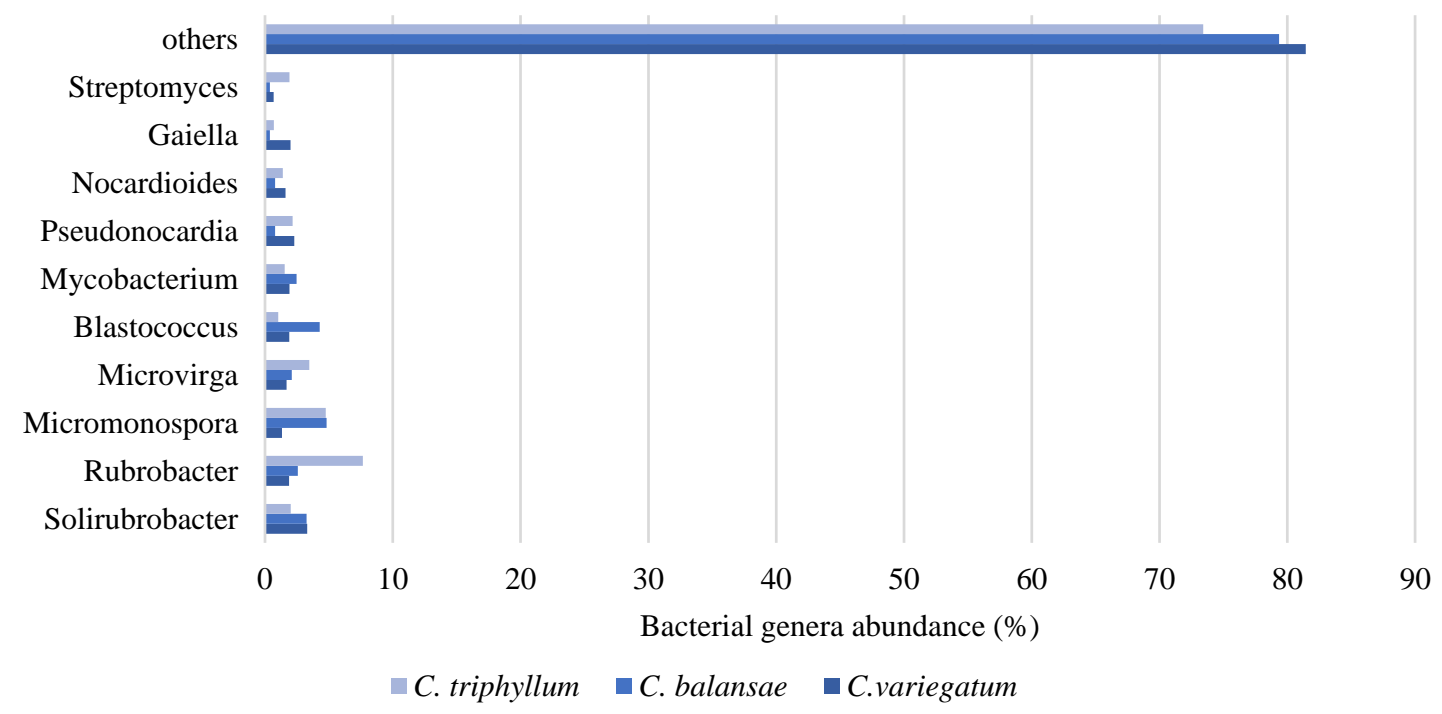

Fig. 15. Taxonomic distribution of identified bacteria in rhizosphere soil samples at genera-level. 


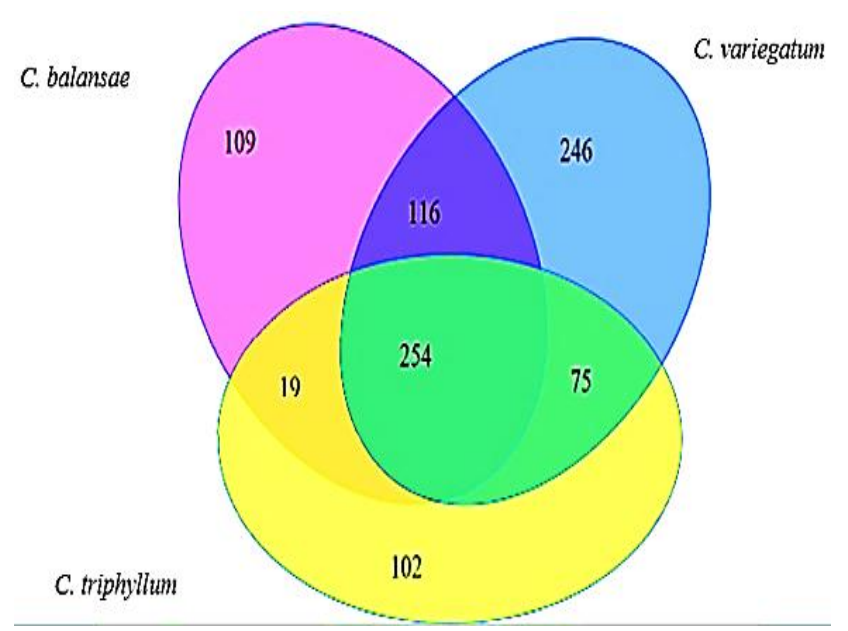

Fig. 16. Diversity of bacteria at species-level in the analysed rhizosphere soil.

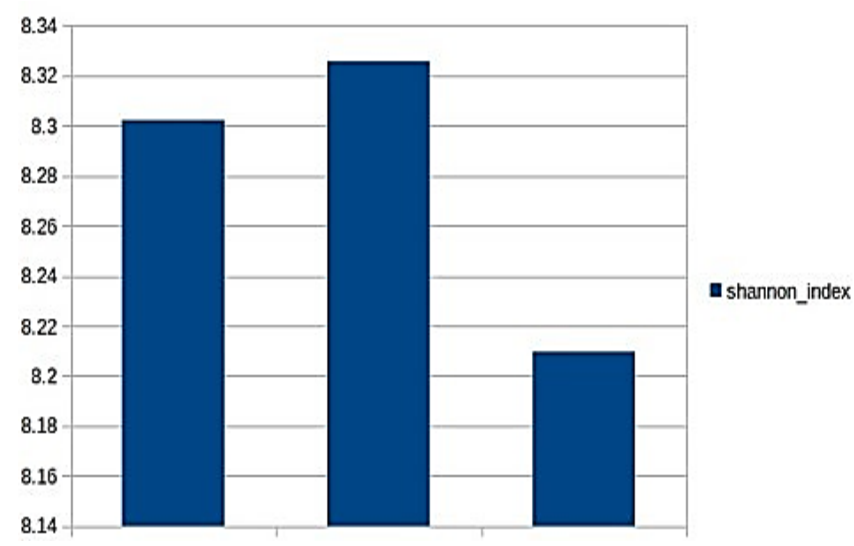

Fig. 17. Shannon index of the analysed rhizosphere soil samples.

\section{Discussion}

According to the daily mineralization curves, carbon mineralization was higher in the first three days and started declining on the $6^{\text {th }}$ day. This shows that organic matter decomposing easily decreased in all three soils. The reversal of the graph between the days reflects that the organic matter in the soil is reduced to forms that decompose more easily thereby making them readily available for microbial utilization. From the $15^{\text {th }}$ day, the curve started to move downwards rapidly in all the three analysed soils. This is due to insufficiency in organic matter utilizable by microorganisms.

The high carbon mineralization observed in $C$. balansae soil indicates that the microbial contents of it that play significant role in mineralization somehow differ from that of its counterparts in terms of quantity and quality. The rate of carbon mineralization recorded in the rhizosphere of $C$. triphyllum $(1.87 \% \mathrm{C})$ and $C$. variegatum $(4.0 \% \mathrm{C})$ is found to be $2.7 \%$ and $2.61 \%$ respectively. It can be deduced that high carbon content does not influence mineralization rate.

Plant and animal remains of the three rhizosphere soils were found at different proportions. The fact that the highest number of eukaryotic microorganisms and the lowest plant residue are in $C$. balansae indicates that the abundance of plant and animal residues affect soil microbiota.

The abundance of the archea Halobacteria was respectively found to be $40 \%$ and $7 \%$ in the rhizosphere of $C$. variegatum and $C$. balansae while in that of $C$. triphyllum none was found (Figs 7-9). This can be attributed to the fact that the bacteria, a halotolerant is usually found in coastal areas where salinity is high. In addition, Nitrososphaera whose percentage abundance was found to be $33 \%$ in C. tryphyllum soil was not found in the other two soils. In C. variegatum and C. triphyllum, Nitrosocosmicus was found to be $40 \%$ and $50 \%$ abundant respectively. In $C$. balansae and $C$. triphyllum, Thermococcaeae was respectively determined to be $14 \%$ and $17 \%$ abundant. These results show that environmental factors such as plant type and location influence microbial diversity in the plant rhizosphere.

Actinobacteria is the most important because of the significant role it plays in agriculture. In soil, Actinobacteria act more like fungi, breaking down organic matter thereby making it readily available for plant utilization. The order Actinomycetales was thought for many years to be a group of fungi, thus the name "mycetales" which denotes mycelium. Some members of soil Actinobacteria establish symbiotic relationship with plants, where the plant is supplied with utilizable nitrogen by the bacteria. In addition to antibiotics synthesis, Streptomyces - a prominent member of the Actinobacteria group -and other members of the Actinobacteria group play a substantial role in soil buffering (Hogan 2010). Also, in the rhizosphere of $C$. variegatum, $C$. balansae and C. triphyllum, Acidobacteria was found at a percentage abundance of $8.02,7.473$ and $2.935 \%$ respectively. It was determined that Acidobacteria found in all soils belonging to different physiological characteristics were not sufficiently represented in culture (Barns et al. 2007). Acidobacteria are generally regarded as oligotrophic due to their growth in low organic environments (Kielak et al. 2016).

The high rate of nitrogen mineralization recorded in $C$. balansae rhizosphere - despite having low nitrogen content - is attributed to the proliferation of Azospirillum and Nitrospira within it, these bacterial genera were found to play significant role in nitrogen cycle. Azospirillum converts atmospheric nitrogen into utilizable nitrogen for plant assimilation thereby promoting plant growth (Katsy 2014, Madigan et al. 2003, Rosenberg 2013). Azospirillum can also alter the form of plant nutrients such as nitrogen and phosphorus to make them more available to plants. However, the amount of nitrogen fixed by Azospirillum via biological nitrogen fixation is still debated (Bashan \& de-Bashan 2010). By synthesizing antioxidants, Azospirillum aid plants in alleviating stress due to drought or flood (Fukami et al. 2018). Nitrospira a ubiquitous bacteria -in the second step of nitrogen fixation plays a prominent role in nitrogen fixation by oxidizing nitrite (Koch et al. 2015). Members of the genus 
were assumed to be nitrite oxidizers because of their possession of nitrite oxidoreductase genes (Pester et al. 2014). Since the discovery of nitrifying bacteria, it was acknowledged that nitrification is a two-step process, though it is energetically unfavourable for one organism to accomplish the two steps (Costa et al. 2006). Recently, Nitrospira -Comammox bacteria- with the ability of performing the two steps of nitrification has been reported (Daims et al. 2015, Palomo et al. 2016, van Kessel et al. 2015). The manner through which bacteria contribute to nitrogen cycle was redefined with the discovery - within Nitrospira genus - of Commamox bacteria, thereby making future studies towards it crucial (van Kessel et al. 2015). With these new findings, there is the likelihood of adopting the complete nitrification process in engineered systems because of its low emission of greenhouse gases (Rodriguez-Caballero et al. 2013).

Solibacter usitatus -found in C. balansae rhizospherereduces nitrate because of its possession of norB gene. Phylogenetically candidatus $S$. usitatus and Koribacter versatilis are closely related. A substantial role is played by Koribacter in regulating $\mathrm{CO}_{2}$ emission. Previous studies have shown that $20 \%$ of $\mathrm{CO}_{2}$ emitted into the atmosphere is reduced by CO-oxidizing bacteria (Campbell 2014, Kishimoto et al. 1991). The high mineralization rate recorded in $C$. balansae rhizosphere despite its low nitrogen and carbon content can be attributed to the high abundance of the aforesaid bacteria.

\section{References}

1. Alali, F.Q., Tawaha, K. \& El-Elimat, T. 2007. Determination of (-)-demecolcine and (-)-colchicine content in selected Jordanian Colchicum species. Pharmazie, 62(10): 739-42.

2. Alef, K. \& Nannipieri, P. 1995. Soil respiration, pp. 214-215. In: Alef, K., Nannipieri, P. (Eds). Methods in applied soil microbiology and biochemistry. Academic press, New york.

3. Allison, L. \& Moodie, C. 1965. Carbonate. pp. 1379-1398. In: In: Black, C., Evans, D., Ensminger, L., White, J., Clark, F., Dinauer, R. (Eds). Methods of soil Analysis. American society of Agronomy Inc., Wisconsin.

4. Ayilara, M.S., Olanrewaju, O. S., Babalola, O. O. \& Odeyemi, O. 2020. Waste Management through Composting: Challenges and Potentials. Sustainability, 12: 4456.

5. Barns, S., Cain, E., Sommerville, L. \& Kuske, C. R. 2007. Acidobacteria phylum sequences in uranium-contaminated subsurface sediments greatly expand the known diversity within the phylum. Applied and Environmental Microbiology, 73(9): 3113.

6. Bashan, Y. \& de-Bashan, L. 2010. How the plant growthpromoting bacterium Azospirillum promotes plant growth-A critical assessment. Advances in Agronomy, $108,77-136$

7. Berg, G., Rybakova, D., Grube, M. \& Köberl, M. 2016. The plant microbiome explored: Implications for experimental botany. Journal of Experimental Botany, 67(4): 995-1002.

\section{Conclusion}

Carbon and nitrogen mineralization in $C$. balansae, $C$. variegatum and $C$. triphyllum rhizosphere were evaluated in this study. Soil microbial diversity and density were demonstrated to be influenced by biological as well as the soil physico-chemical properties. Carbon and nitrogen mineralization rates not only depend on the soil physicochemical properties, but also vary depending on the type and density of microorganisms in the soil. C. balansae soil exhibited the highest carbon and nitrogen mineralization rate despite having lower carbon and nitrogen content than the other two soils.

Ethics Committee Approval: Since the article does not contain any studies with human or animal subject, its approval to the ethics committee was not required.

Author Contributions: Concept: İ.E., C.D., S.D., Desing: İ.E., C.D., S.D., Execution: İ.E., C.D., S.D., Material supplying: İ.E., C.D., S.D., Data acquisition: İ.E., C.D., S.D., Data analysis/interpretation: İ.E., C.D., S.D., Writing: İ.E., C.D., Z.K.S., S.D., Critical review: İ.E., C.D., S.D.

Conflict of Interest: The authors have no conflicts of interest to declare.

Funding: The study was supported by the Çukurova University Research Projects Unit with project number FYL-2020-12926.

8. Berg, M., Kiers, E., Driessen, G., Van Der Heijden, M., Kooi, B., Kuenen, F., Lieftıng, M., Verhoef, H. \& Ellers, J. 2010. Adapt or disperse: Understanding species persistence in a changing world. Global Change Biology, 16(2): 587-598.

9. Bolyen, E., Rideout, J.R., Dillon, M.R., Bokulich, N.A., Abnet, C.C., Al-Ghalith, G.A., Alexander, H., Alm, E.J., Arumugam, M., Asnicar, F., Bai, Y, Bisanz, J.E., Bittinger, K., Brejnrod, A., Brislawn, C.J., Brown, C.T., Callahan, B.J., Caraballo-Rodríguez, A.M., Chase, J., Cope, E.K., Da Silva, R., Diener, C., Dorrestein, P.C., Douglas, G.M., Durall, D.M., Duvallet, C., Edwardson, C.F., Ernst, M., Estaki, M., Fouquier, J., Gauglitz, J.M., Gibbons, S.M., Gibson, D.L., Gonzalez, A., Gorlick, K., Guo, J., Hillmann, B., Holmes, S., Holste, H., Huttenhower, C., Huttley, G.A., Janssen, S., Jarmusch, A.K., Jiang, L., Kaehler, B.D., Kang, K.B., Keefe, C.R., Keim, P., Kelley, S.T., Knights, D., Koester, I., Kosciolek, T., Kreps, J., Langille, M.G.I., Lee, J., Ley, R., Liu, Y.X., Loftfield, E., Lozupone, C., Maher, M., Marotz, C., Martin, B.D., McDonald, D., McIver, L.J., Melnik, A.V., Metcalf, J.L., Morgan, S.C., Morton, J.T., Naimey, A.T., Navas-Molina, J.A., Nothias, L.F., Orchanian, S.B., Pearson, T., Peoples, S.L., Petras, D., Preuss, M.L., Pruesse, E., Rasmussen, L.B., Rivers, A., Robeson, M.S., Rosenthal, P., Segata, N., Shaffer, M., Shiffer, A., Sinha, R., Song, S.J., Spear, J.R., Swafford, A.D., Thompson, L.R., Torres, P.J., Trinh, P., Tripathi, A., Turnbaugh, P.J., Ul-Hasan, S., van der Hooft, J.J.J., Vargas, F., Vázquez-Baeza, Y., Vogtmann, E., von Hippel. M., Walters, W., Wan, Y., Wang, M., Warren, J., Weber, K.C., Williamson, C.H.D., Willis, A.D., Xu, Z.Z., Zaneveld, J.R., Zhang, Y., Zhu, Q., Knight, R. \& Caporaso, J.G. 2019. 
Reproducible, interactive, scalable and extensible microbiome data science using QIIME 2. Nature Biotechnology, 37, 852-857.

10. Bouyoucos, G. 1951. A Recalibration of the Hydrometer Method for Making Mechanical Analysis of Soils1. Agronomy Journal, 43(9): 434-438.

11. Braga, R., Dourado, M. \& Araújo, W. 2016. Microbial interactions: Ecology in a molecular perspective. Brazilian Journal of Microbiology, 47, 86-98.

12. Bremmer, J. 1965. Total nitrogen. pp 1149-1178. In: Black, C., Evans, D., Ensminger, L., White, J., Clark, F. \& Dinauer, R. (Eds). Methods of soil analysis. American society of Agronomy Inc., Madison.

13. Campbell, B. 2014. The family Acidobacteriaceae. pp 405415. In Rosenberg, E., Delong, E., Lory, S., Stackebrandt, E. \& Thompson, E. (Eds). The prokaryotes. Springer, Berlin.

14. Chaparro, J., Badri, D., Bakker, M., Sugiyama, A., Manter, D. \& Vivanco, J. 2013. Root exudation of phytochemicals in Arabidopsis follows specific patterns that are developmentally programmed and correlate with soil microbial functions. PloS One, 8(2): e55731.

15. Classen, A., Sundqvist, M., Henning, J., Newman, G., Moore, J., Cregger, M., Moorhead, L. \& Patterson, C. 2015. Direct and indirect effects of climate change on soil microbial and soil microbial-plant interactions: What lies ahead? Ecosphere, 6(8): 1-21.

16. Compant, S., Samad, A., Faist, H. \& Sessitsch, A. 2019. A review on the plant microbiome: Ecology, functions, and emerging trends in microbial application. Journal of Advanced Research, 19, 29-37.

17. Costa, E., Pérez, J. \& Kreft, J. 2006. Why is metabolic labour divided in nitrification? Trends in Microbiology, 14(5): 213-219.

18. Daims, H., Lebedeva, E, Pjevac, P., Han, P., Herbold, C., Albertsen, M., Jehmlich, N., Palatinszky, M., Vierheilig, J., Bulaev, A., Kirkegaard, R., von Bergen, M., Rattei, T., Bendinger, B., Nielsen, P. \& Wagner, M. 2015. Complete nitrification banny Nitrospira bacteria. Nature, 528(7583): 504-509.

19. Demiralay, I. 1993. Toprak fiziksel analizleri. Atatürk üniversitesi Ziraat fakültesi yayınları, $131 \mathrm{pp}$.

20. Duchaufour, P. 1970. Précis de Pédologie. Masson et Cie, Paris, 435-436 pp.

21. Evans, W.C. 2002. Trease and Evans. Pharmacognosy, WB Saunders. Edinburgh, London: 72 pp.

22. Fukami, J., Cerezini, P., \& Hungria, M. 2018. Azospirillum: Benefits that go far beyond biological nitrogen fixation. $A M B$ Express, 8, 73. https://doi.org/10.1186/s13568-018-0608-1

23. Gökçeoğlu, M. 1979. Bazı bitki organlarındaki azot, fosfor ve potasyumun bir vegetasyon periyodundaki değişimi. Doğa tarım ve ormancılık, 3, 192-199.

24. Hassani, M., Durán, P. \& Hacquard, S. 2018. Microbial interactions within the plant holobiont. Microbiome, 6, 58 .

25. Hogan, C. 2010. Bacteria. In: Draggon, S. (Eds). Encyclopaedia of Earth. National council for science and the environment, Washington DC.
http://editors.eol.org/eoearth/wiki/Bacteria (Date accessed: 18.09.2017)

26. Jackson, M. 1958. Soil chemical analysis. Prentice Hall Inc, Engle-wood Cliffs, 111-133 pp.

27. Katsy, E. 2014. Plasmid rearrangements and changes in cell-surface architecture and social behaviour of Azospirillum brasilense, 81-97. In: Katsy, E (Eds). Plasticity in plant-growth-promoting and phytopathogenic bacteria. Springer, New york.

28. Kielak, A., Barreto, C., Kowalchuk, G., van Veen, J. \& Kuramae, E. 2016. The Ecology of Acidobacteria: Moving beyond Genes and Genomes. Frontiers in Microbiology, 7, 744 .

29. Kishimoto, N., Kosako, Y. \& Tano, T. 1991. Acidobacterium capsulatum gen. nov., sp. nov.: An acidophilic chemoorganotrophic bacterium containing menaquinone from acidic mineral environment. Current Microbiology, 22, 1-7.

30. Koch, H., Lücker, S., Albertsen, M., Kitzinger, K., Herbold, C., Spieck, E., Nielsen, P. H., Wagner, M. \& Daims, H. 2015. Expanded metabolic versatility of ubiquitous nitrite-oxidizing bacteria from the genus Nitrospira. Proceedings of the National Academy of Sciences, 112(36): 11371-11376.

31. Lakshmanan, V., Selvaraj, G. \& Bais, H. 2014. Functional soil microbiome: Belowground solutions to an aboveground problem. Plant Physiology, 166(2): 689-700.

32. Lemee, G. 1967. Investigations sur la mineralization de L'azote et son evolution annuelle dans des humus forestiers in situ. Oecologia, 2, 285-324.

33. Madigan, M., Martinko, J. \& Parker, J. 2003. Brock biology of microorganisms. Prentice Hall,Pearson Education Inc., New York, 606-620 pp.

34. Mendes, R. \& Raaijmakers, J. 2015. Cross-kingdom similarities in microbiome functions. The ISME Journal, 9(9): 1905-1907.

35. Olsen, S. 1954. Estimation of available phosphorus in soils by extraction with sodium bicarbonate. USDA circular $\mathrm{Nr}$ 939, US Govt. Print. Office, Washington, D.C.

36. Palomo, A., Jane Fowler, S., Gülay, A., Rasmussen, S., Sicheritz-Ponten, T. \& Smets, B. 2016. Metagenomic analysis of rapid gravity sand filter microbial communities suggests novel physiology of Nitrospira spp. The ISME Journal, 10(11): 2569-2581.

37. Persson, K. 2007. Nomenclatural synopsis of the genus Colchicum (Colchicaceae), with some new species and combinations. Botanische Jahrbücher Für Systematik, Pflanzengeschichte Und Pflanzengeographie, 127(2): 165242.

38. Pester, M., Maixner, F., Berry, D., Rattei, T., Koch, H., Lücker, S., Nowka, B., Richter, A., Spieck, E., Lebedeva, E., Loy, A., Wagner, M. \& Daims, H. 2014. NxrB encoding the beta subunit of nitrite oxidoreductase as functional and phylogenetic marker for nitrite-oxidizing Nitrospira. Environmental Microbiology, 16(10): 3055-3071.

39. Rodriguez-Caballero, A., Ribera, A., Balcázar, J. \& Pijuan, M. 2013. Nitritation versus full nitrification of ammonium- 
rich wastewater: Comparison in terms of nitrous and nitric oxides emissions. Bioresource Technology, 139, 195-202.

40. Rosenberg, E. 2013. The Prokaryotes: Alphaproteobacteria and Betaproteobacteria (p. 1012). https://doi.org/10.1007/978-3-642-30197-1

41. Thrall, P., Hochberg, M., Burdon, J. \& Bever, J. 2007. Coevolution of symbiotic mutualists and parasites in a community context. Trends in Ecology \& Evolution, 22(3): $120-126$.

42. Toplan, G.G., Gurer, C. \& Mat, A. 2016. Importance of Colchicum species in modern therapy and its significance in Turkey. Journal of the Faculty of Pharmacy of İstanbul University, 46(2): 129-144.
43. Uysal, E. \& Kaya, E. 2019. Türkiye'de doğal olarak yetişen kır sümbülü (Bellevalia spp.) türlerinin yetiştiği topraklara ait özellikler. Mediterrenean Agricultural sciences, 32, 3541 .

44. van der Putten, W., Bardgett, R., Bever, J., Bezemer, T., Casper, B., Fukami, T., Kardol, P., Klironomos, J., Kulmatiski, A., Schweitzer, J., Suding, K., Van de Voorde, T. \& Wardle, D. 2013. Plant-soil feedbacks: The past, the present and future challenges. Journal of Ecology, 101(2): 265-276.

45. van Kessel, M., Speth, D., Albertsen, M., Nielsen, P., Op den Camp, H., Kartal, B., Jetten, M. \& Lücker, S. 2015. Complete nitrification by a single microorganism. Nature, 528(7583): 555-559. 